\title{
ZMIANY W ZAKRESIE ŚRODKÓW KARNYCH W ŚWIETLE NOWELIZACJI KODEKSU KARNEGO Z DNIA 13 CZERWCA 2019 R.
}

\section{Uwagi wprowadzające}

Przedmiotem niniejszego opracowania będą zmiany w systemie środków karnych, wynikające z nowelizacji Kodeksu karnego z dnia 13 czerwca 2019 r. ${ }^{1}$ Trzeba nadmienić, że to kolejna - w ciągu ponad 20 lat obowiązywania K.k. z 1997 r. ${ }^{2}$ - istotna nowelizacja odnosząca się do środków karnych, co prowadzi do wniosku, że w sferze środków reakcji na przestępstwo, najpoważniejszymi zmianami objęto właśnie tę grupę środków penalnych ${ }^{3}$. Dość powiedzieć, że pierwotny katalog liczył osiem środków karnych, następnie ich liczba zwiększyła się o pięć nowych instytucji. W ciągu tego okresu swój normatywny kształt zmieniła znakomita większość środków karnych. Zmiany w systemie środków karnych niemal zawsze miały charakter merytoryczny i polegały na uzupełnieniu katalogu środków karnych o nowe instrumenty lub na modyfikacji podstaw

* Dr, Katolicki Uniwersytet Lubelski Jana Pawła II; e-mail: dd23@kul.pl, ORCID ID: https:/ / orcid.org/0000-0002-7062-3145.

1 Ustawa z dnia 13 czerwca 2019 r. o zmianie ustawy - Kodeks karny oraz niektórych innych ustaw, http://orka.sejm.gov.pl/opinie8.nsf/nazwa/3451_u/\$file/3451_u.pdf [dostęp: 8.07.2019 r.]. W dniu 28 czerwca 2019 r. Prezydent RP działając na podstawie art. 122 ust. 3 Konstytucji RP skierował powyższą ustawę do Trybunału Konstytucyjnego w trybie kontroli prewencyjnej.

2 Ustawa z dnia 6 czerwca 1997 r. - Kodeks karny, tekst jednolity: Dz. U. z 2019 r. poz. 1950 z późn. zm. (dalej: K.k.).

3 Zob. Z. Sienkiewicz, Z problematyki środków karnych, w: Węzłowe problemy prawa karnego, kryminologii i polityki kryminalnej. Księga pamiątkowa ofiarowana Profesorowi Andrzejowi Markowi, red. V. Konarska-Wrzosek, J. Lachowski, J. Wójcikiewicz, Warszawa 2010, s. 478. 
orzekania już funkcjonujących środków, z reguły w kierunku poszerzenia zakresu ich stosowania ${ }^{4}$. Najpoważniejszej jak dotąd transformacji systemu środków karnych dokonano w wyniku nowelizacji K.k. z dnia 20 lutego 2015 r. Z jednolitego dotychczas systemu środków karnych wyodrębniono przepadek oraz środki kompensacyjne w postaci obowiązku naprawienia szkody lub zadośćuczynienia za doznaną krzywdę oraz nawiązki i umieszczono w nowym rozdziale (Va K.k.). W ten sposób ustawodawca uzupełnił system środków penalnych o nową kategorię ${ }^{5}$.

Przekształcenia w systemie środków karnych zdają się potwierdzać tezę o wzrastającej roli tych instrumentów polityki karnej. Można przypuszczać, że ich znaczenie będzie jeszcze większe niż obecnie ${ }^{6}$. Stały się one bardzo elastycznymi narzędziami, za pomocą których ustawodawca kreuje politykę karną, zwłaszcza gdy zachodzi konieczność dokonania jej korekty i nadania bardziej represyjnego i ogólnoprewencyjnego kierunku. Inną zauważalną tendencją stało się upodobnienie środków karnych do środków zabezpieczających. Widocznym tego symptomem stała się możliwość (niekiedy wręcz obowiązek) dożywotniego orzekania wielu środków karnych. Przekształcenia środków karnych wynikające z nowelizacji K.k. z dnia 13 czerwca 2019 r. wpisują się w te tendencje. Oczywiście trzeba mieć świadomość, że zmiany w zakresie środków karnych wynikające z przedmiotowej nowelizacji nie były ani najważniejsze, ani najdalej idące. Ogólnie rzecz biorąc, cała nowelizacja spotkała się z olbrzymią falą krytyki, zarówno jeśli chodzi o tryb procedowania nad nią, jak i charakter projektowanych rozwiązań, dotyczących zarówno części ogólnej, jak i szczególnej K.k. W odniesieniu do środków karnych trzeba wyraźnie zaznaczyć, że uchwalone ostatecznie zmiany były dalej idące, niż zakładał pierwotny projekt nowelizacji K.k. przygotowywany przez

4 Zob. R.A. Stefański, Nowe środki karne i problem ich spójności z systemem Kodeksu karnego, w: Problem spójności prawa karnego z perspektywy jego nowelizacji, red. A. Marek, T. Oczkowski, Warszawa 2011, s. 91-110.

5 Szerzej zob. D. Szeleszczuk, Środki karne w świetle nowelizacji Kodeksu karnego z dnia 20 lutego 2015 r., Studia Prawnicze KUL 2015, nr 4, s. 75-87.

6 Proponuje się przykładowo wprowadzenie środka karnego w postaci zakazu korzystania z serwisów społecznościowych, zob. K. Mamak, Zakaz korzystania z serwisów społecznościowych. Propozycja wprowadzenia nowego środka karnego, Czasopismo Prawa Karnego i Nauk Penalnych 2016, z. 3. 
Ministerstwo Sprawiedliwości, datowany na 25 stycznia 2019 r. ${ }^{7}$ Nie przewidywał on modyfikacji w zakresie zakazu prowadzenia pojazdów, obejmując zmianami jedynie zakaz przebywania w określonych środowiskach lub miejscach, kontaktowania się z określonymi osobami, zbliżania się do określonych osób lub opuszczania określonego miejsca pobytu bez zgody sądu, jak również nakaz okresowego opuszczenia lokalu zajmowanego wspólnie z pokrzywdzonym oraz zakaz kontaktowania się z określoną osobą.

Zmiany w zakresie środków karnych są ukierunkowane na zwalczanie dwojakiego rodzaju przestępczości: pedofilskiej oraz komunikacyjnej. Nowelizacja przewidywała zaostrzenie środków reakcji prawnokarnej stosowanych wobec sprawców przestępstw przeciwko wolności seksualnej i obyczajności, w szczególności związanych z seksualnym wykorzystaniem małoletnich oraz sprawców przestępstw przeciwko bezpieczeństwu w komunikacji. Zmianami zostały objęte:

a) zakaz prowadzenia działalności związanej z wychowaniem, leczeniem, edukacją małoletnich lub opieką nad nimi (art. 1 pkt 7 ustawy nowelizującej);

b) zakaz przebywania $\mathrm{w}$ określonych środowiskach lub miejscach, kontaktowania się z określonymi osobami, zbliżania się do określonych osób, zakaz opuszczania określonego miejsca pobytu bez zgody sądu (art. 1 pkt 8 ustawy nowelizującej);

c) nakaz okresowego opuszczenia lokalu zajmowanego wspólnie z pokrzywdzonym (art. 1 pkt 8 ustawy nowelizującej);

d) zakaz prowadzenia pojazdów (art. 1 pkt 9 ustawy nowelizującej).

Wprowadzone zmiany wywołują poważne wątpliwości, zarówno jeśli chodzi o interpretację, jak i celowość ich uchwalenia. Dotyczą one również tego, czy odpowiadają one podstawowym polityczno-kryminalnym założeniom K.k. z 1997 r., czy też są wyrazem nowej filozofii karania. Udzielenie odpowiedzi na to pytanie, będące zasadniczym celem pracy, wymaga $\mathrm{w}$ pierwszym rzędzie zastanowienia się nad tym, czy ingerencja ustawodawcy w system środków karnych, ukształtowany nowelizacją z 2015 r. była dostatecznie uzasadniona. W doktrynie wskazuje się następujące przesłanki dopuszczające interwencję ustawodawcy:

7 Projekt z dnia 25 stycznia 2019 r. ustawy o zmianie ustawy - Kodeks karny oraz niektórych innych ustaw, https://legislacja.rcl.gov.pl/docs//2/12320403/12565603/125 65604/dokument378684.pdf [dostęp: 19.02.2019 r.]. 
1) ustawa zawiera błędy lub luki, których nie można usunąć w drodze wykładni, a które uniemożliwiają stosowanie przepisów;

2) ustawa zawiera rozwiązania uniemożliwiające realizację funkcji, które miała spełniać, a w drodze wykładni nie jest możliwe skorygowanie tych wad;

3) powstała konieczność dostosowania prawa karnego do zobowiązań międzynarodowych, $\mathrm{w}$ tym prawa unijnego;

4) ingerencja prawnokarna jest niezbędna $\mathrm{w}$ związku z powstaniem nowych zjawisk i zagrożeń w obszarze przestępczości ${ }^{8}$.

Uzasadnienie nowelizacji dosyć wyraźnie wskazuje, że zasadniczą przyczyną zmian, przynajmniej w interesującym nas obszarze, była dysfunkcjonalność analizowanych środków karnych w ich dotychczasowym kształcie, zwłaszcza z punktu widzenia celów, które powinny one realizować. Ze względu na zasadnicze odrębności pomiędzy środkami karnymi mającymi za przedmiot ochrony dobro małoletnich oraz bezpieczeństwo w komunikacji, zostaną one omówione oddzielnie.

\section{Przekształcenia systemu prawnokarnych środków ochrony małoletnich}

Spośród licznych nowelizacji K.k., co najmniej kilka było motywowanych chęcią wzmocnienia ochrony dzieci przed wykorzystaniem seksualnym . Wyznaczyły one pewne kierunki zmian w prawie karnym, które zasadniczo zmierzały do zwiększenia represyjności prawa karnego, poszerzenia obszaru kryminalizacji o czyny znajdujące się "na przedpolu” naruszenia dobra prawnego oraz wprowadzenia rozwiązań o charakterze ochronno-prewencyjnym w postaci nowych środków karnych, środków zabezpieczających oraz ograniczenia możliwości zatarcia skazania ${ }^{10}$.

8 Zob. A. Zoll, Głos w dyskusji, w: Czy trzeba zmieniać kodeks karny? Materiały z konferencji naukowej „Nowelizacja kodeksu karnego”, Warszawa, 10 lutego 2003 r., Warszawa 2003, s. 12-13.

9 Chodzi o ustawy nowelizujące K.k. z dnia: 18 marca 2004 r., Dz. U. z 2004 r. Nr 69, poz. 626; 27 lipca 2005 r., Dz. U. z 2005 r. Nr 163, poz. 1363; 24 października 2008 r., Dz. U. z 2008 r. Nr 214, poz. 1344; 5 listopada 2009 r., Dz. U. z 2009 r. Nr 206, poz. 1589.

10 Zob. K. Wiak, Nowe tendencje w zakresie przeciwdziałania przestępstwom zwiazanym $z$ wykorzystywaniem dzieci w celach seksualnych na tle nowelizacji Kodeksu karnego, w: Nauki 
Wyrazem tej ostatniej tendencji jest wyodrębnienie osobnej kategorii instrumentów prawnokarnych, zmierzających do ochrony małoletnich przed kontynuowaniem działalności przestępczej przez osoby, które z pobudek seksualnych dopuszczają się groźnych przestępstw. Tworzą one swoistego rodzaju system, na który składają się niektóre środki karne, obowiązki o charakterze probacyjnym oraz część spośród środków zabezpieczających. Najistotniejszym elementem tego systemu są środki karne ${ }^{11}$. Od 2005 r., kiedy to w wyniku nowelizacji K.k., powstały zręby tego systemu, podlegał on licznym modyfikacjom, których kierunek był determinowany paradygmatem zwiększenia punitywności oraz intensywności ochrony małoletnich przed wykorzystaniem seksualnym. Nowelizacja z 2019 r. stanowi kontynuację tego procesu. W swoich założeniach zmierza ona $\mathrm{w}$ istocie do uszczelnienia systemu ochrony małoletnich.

\section{Ratio legis}

Opierając się jedynie na warstwie deskryptywnej uzasadnienia projektu nowelizacji trzeba podkreślić, że „zasadniczym założeniem, które legło u podstaw prac nad projektem zmian Kodeksu karnego była potrzeba wzmocnienia ochrony prawnokarnej w zakresie czynów godzących w tak fundamentalne dobra prawne jak życie i zdrowie człowieka, wolność

penalne wobec szybkich przemian socjokulturowych. Księga jubileuszowa Profesora Mariana Filara, t. 1, red. A. Adamski i in., Toruń 2012, s. 493.

11 Do tego systemu zaliczam te środki karne, które poprzez ukształtowanie przesłanek ich orzekania zostały normatywnie związane z typem czynu zabronionego o charakterze pedofilskim. Chodzi zatem o środki karne w postaci: zakazu prowadzenia działalności związanej z wychowaniem, leczeniem, edukacją małoletnich lub z opieką nad nimi, zakazu przebywania w określonych środowiskach lub miejscach, kontaktowania się z określonymi osobami, zbliżania się do określonych osób lub opuszczania określonego miejsca pobytu bez zgody sądu, nakazu okresowego opuszczenia lokalu zajmowanego wspólnie z pokrzywdzonym. Nie oznacza to oczywiście, że pozostałe środki karne (pozbawienie praw publicznych, zakaz zajmowania określonego stanowiska, wykonywania określonego zawodu lub prowadzenia określonej działalności gospodarczej, podanie wyroku do publicznej wiadomości), przepadek czy środki kompensacyjne nie mogą znaleźć zastosowania do sprawców przestępstw o charakterze pedofilskim. 
seksualna czy własność"12. Realizacji tych celów ma służyć odpowiednie ukształtowanie rodzaju i wysokości sankcji karnej grożącej za dany typ przestępstwa, uwzględniające potrzebę surowej represji wobec sprawców tych czynów, które budzą silną społeczną potrzebę odpłaty i napiętnowania. W opinii projektodawców, obecny stan prawny nie odpowiada postulatom wynikającym z funkcji ochronnej prawa karnego, przez co nie zapewnia wystarczających narzędzi dla ograniczenia przestępczości i zabezpieczenia istotnych wartości społecznych. W szczególności przewidywane dotychczas sankcje za przestępstwa najcięższe, skierowane przeciwko dobrom prawnym o wysokiej randze w hierarchii dóbr prawnych, nie odzwierciedlają $\mathrm{w}$ pełni stopnia społecznej szkodliwości tych przestępstw, prowadząc do zbyt łagodnego traktowania ich sprawców i naruszając w ten sposób społeczne poczucie sprawiedliwości ${ }^{13}$.

Racjonalizacji dla podniesienia stopnia represyjności systemu prawa karnego dostarcza projektodawcom pozytywna funkcja sprawiedliwościowej teorii proporcjonalności wywodzona z art. 31 ust. 3 Konstytucji Rzeczypospolitej Polskiej, której towarzyszy nakaz zapewnienia dostatecznej ochrony dóbr konstytucyjnych, zarówno o charakterze indywidualnym, jak i kolektywnym. Według autorów projektu, zaniechanie ustanowienia odpowiedniej ochrony praw człowieka lub innych interesów jednostki, można traktować jako szczególną formę ingerencji w dane prawo lub interes ${ }^{14}$.

Powyższe okoliczności uzasadniają podjęcie działań legislacyjnych zmierzających do zwiększenia surowości sankcji karnych i ukształtowania instytucji wpływających na wymiar kary w taki sposób, że ukierunkowują one decyzję sądu w stronę ograniczenia możliwości korzystania z redukowania sankcji karnej lub rozszerzają możliwość zwiększenia represji karnej wobec sprawców przestępstw o wysokim stopniu karygodności ${ }^{15}$. W odniesieniu do przestępczości pedofilskiej stwierdza się, że niedostateczna ochrona konstytucyjnych wartości, w postaci życia, zdrowia i wolności seksualnej uzasadnia zwiększenie poziomu represyjności

12 Sejm Rzeczypospolitej Polskiej VIII kadencja, Uzasadnienie z dnia 14 maja 2019 r. projektu ustawy o zmianie ustawy - Kodeks karny oraz niektórych innych ustaw, Druk Nr 3451, http:/ / orka.sejm.gov.pl/Druki8ka.nsf/0/996CE307123D03FEC12583FA0069E8F 2/\%24File/3451.pdf [dostęp: 5.06.2019 r.].

$\begin{aligned}{ }_{13} & \text { Zob. tamże. } \\ { }_{14} & \text { Zob. tamże. } \\ & \text { Zob. tamże. }\end{aligned}$ 
prawa karnego. W związku z tym przewiduje się zaostrzenie środków reakcji prawnokarnej stosowanych wobec sprawców przestępstw przeciwko wolności seksualnej i obyczajności, w szczególności zaś związanych z seksualnym wykorzystaniem małoletnich. Wyraża się to zarówno $\mathrm{w}$ podwyższeniu granic ustawowego zagrożenia wielu typów czynów zabronionych, w tym naturalnie również przestępstw o charakterze pedofilskim, a także w nadaniu bardziej represyjnego charakteru środkom karnym. W perspektywie realizacji celów wyznaczonych przez ustawodawcę, za kluczowe zostały uznane środki karne: zakazu prowadzenia działalności związanej z wychowaniem, edukacją, leczeniem małoletnich lub z opieką nad nimi (art. 39 pkt 2a K.k.); zakazu przebywania w określonych środowiskach lub miejscach, kontaktowania się z określonymi osobami, zbliżania się do określonych osób lub opuszczania określonego miejsca pobytu bez zgody sądu (art. 39 pkt 2b K.k.); nakazu okresowego opuszczenia lokalu zajmowanego wspólnie z pokrzywdzonym (art. 39 pkt 2e K.k.).

\section{Zmiany $\mathrm{w}$ zakresie zakazu prowadzenia działalności związanej $\mathrm{z}$ wychowaniem, edukacją, leczeniem małoletnich lub z opieką nad nimi (art. 39 pkt 2a K.k.)}

Projektowane zmiany obejmują przepis $§ 1$ a art. 41 K.k., który określa przesłanki i tryb orzekania zakazu określonego w art. 39 pkt 2a K.k. W zakresie przesłanek orzekania zakazu nowelizacja nie przewiduje żadnych zmian. Od dnia 1 października 2017 r. - tj. od czasu wejścia w życie nowelizacji K.k. wynikającej z ustawy z dnia 13 maja 2016 r. o przeciwdziałaniu zagrożeniom przestępczością na tle seksualnym ${ }^{16}$ - przesłankami orzeczenia zakazu są: skazanie na karę pozbawienia wolności za umyślne przestępstwo przeciwko życiu lub zdrowiu na szkodę małoletniego oraz skazanie za przestępstwo przeciwko wolności seksualnej lub obyczajności na szkodę małoletniego. Nowelizacja zakłada natomiast ujednolicenie trybu orzekania tego środka karnego, przewidując, że będzie on miał charakter wyłącznie obligatoryjny. $\mathrm{W}$ dotychczasowym stanie prawnym zakaz

16 Ustawa z dnia 13 maja 2016 r. o przeciwdziałaniu zagrożeniom przestępczością na tle seksualnym, tekst jednolity: Dz. U. z 2020 r. poz. 152. 
występował w postaci fakultatywnej bądź obligatoryjnej. Możliwość jego terminowego lub dożywotniego zastosowania zachodziła w razie skazania za umyślne przestępstwo przeciwko życiu lub zdrowiu na szkodę małoletniego. Obowiązek jego orzeczenia powstawał w razie pierwszego skazania za przestępstwo przeciwko wolności seksualnej lub obyczajności na szkodę małoletniego. W tym wypadku sąd mógł orzec zakaz terminowo lub dożywotnio. Ponowne skazanie za umyślne przestępstwo przeciwko życiu lub zdrowiu na karę pozbawienia wolności lub za przestępstwo przeciwko wolności seksualnej lub obyczajności na szkodę małoletniego uzasadniało orzeczenie dożywotniego zakazu.

Jak podkreślono $\mathrm{w}$ motywach ustawodawczych, przyjęcie trybu obligatoryjnego opierało się na założeniu, że:

przestępstwa, za które można orzec wskazany środek karny, odznaczają się na tyle wysokim stopniem społecznej szkodliwości czynu, że zarówno w płaszczyźnie represyjnej, jak i płaszczyźnie prewencyjnej konieczne jest wyłączenie na określony czas w stosunku do sprawcy możliwości podejmowania określonej aktywności zawodowej lub społecznej tudzież ograniczenie w korzystaniu przez skazanego z jego konstytucyjnych swobód. Ta istotna dolegliwość stanowić ma na przyszłość impuls zniechęcający do popełnienia przestępstwa o charakterze seksualnym na szkodę małoletniego lub przestępstwa z użyciem przemocy, w tym także przeciwko osobie najbliższej. Nie można w końcu pomijać, że wzgląd na skuteczną realizację funkcji ochronnej, oraz co się z tym wiąże, należyte zabezpieczenie pokrzywdzonego przestępstwem oraz potencjalnych ofiar wymaga wprowadzenia obligatoryjnego - niezależnego od uznania sędziowskiego - trybu orzekania tych środków. Tylko w ten sposób zostanie zrealizowany zamierzony przez ustawodawcę profilaktyczny cel środków karnych określony jako ochrona przed kontynuowaniem działalności przestępczej przez osoby, które z pobudek seksualnych dopuszczają się groźnych przestępstw ${ }^{17}$.

Zgodzić się trzeba z poglądem, że wprowadzenie obligatoryjnego trybu orzekania środka karnego istotnie zwiększa represyjność uregulowań, prowadząc do zaostrzenia polityki karnej ${ }^{18}$. Rozwiązanie takie niemal zawsze spotyka się z krytyką ze strony doktryny. Przy tej okazji podnoszone są zarzuty ograniczenia konstytucyjnej kompetencji sądu

17 Sejm Rzeczypospolitej Polskiej VIII kadencja, Uzasadnienie z dnia 14 maja 2019 r. projektu ustawy..., s. 5.

18 Zob. M. Melezini, Środki karne jako instrument polityki kryminalnej, Białystok 2013, s. 296. 
do sprawowania wymiaru sprawiedliwości, jak i wprowadzenia sankcji bezwzględnie oznaczonej. Nałożenie obowiązku orzeczenia tego środka karnego ogranicza zakres swobody sądu, czyniąc go jedynie „ustami ustawy" i uniemożliwiając indywidualizację wymiaru kary. Zabieg taki, redukując elastyczność wymiaru sprawiedliwości, jest odczytywany jako wyraz swoistego braku zaufania do sądów ${ }^{19}$ i traktowany jako typowy przykład kształtowania polityki karnej w drodze ustawodawczejej. Taka metoda oddziaływania na politykę karną rodzi niebezpieczeństwo dehumanizacji odpowiedzialności karnej w dwojakim znaczeniu: po pierwsze, w sensie oderwania się przy wymiarze kary od cech indywidualnego sprawcy i traktowania go w kategoriach jednostki statystycznej - jednego ze sprawców czynów określonego rodzaju; po drugie, istnieje także ryzyko dehumanizacji $\mathrm{w}$ takim znaczeniu, że wymiar sprawiedliwości nabiera cech automatyzmu, poprzez fakt, że redukuje się wpływ sędziego na wymiar kary, co sprawia, że czuje się on mniej odpowiedzialny za tę część wyroku²1. Dokonując oceny przyjętej regulacji, trzeba zaznaczyć, że nawet uwzględniając specyfikę czynów wskazanych w art. 41 § 1a K.k., decyzja o nadaniu obligatoryjnego charakteru temu środkowi karnemu i pozbawienie sądu wpływu na jego orzeczenie i możliwości uwzględnienia okoliczności konkretnej sprawy, nie była uzasadniona.

\section{Zmiany dotyczące zakazu przebywania w określonych środowiskach lub miejscach, kontaktowania się z określonymi osobami, zbliżania się do określonych osób lub opuszczania określonego miejsca pobytu bez zgody sądu (art. 39 pkt 2b K.k.)}

Zmiany polegają na dodaniu do art. 41a K.k. nowej jednostki redakcyjnej w postaci § 1a K.k. Ponadto obejmują również przepis art. 41a § 2 K.k. Dodatkowo zdecydowano się na doprecyzowanie treści zakazu kontaktowania się z określonymi osobami (art. 41a § 6 K.k.).

19 Zob. T. Kaczmarek, Nowy polski kodeks karny i jego aksjologiczne i kryminalnopolityczne założenia, Nowa Kodyfikacja Prawa Karnego 1998, t. 3, s. 10-27.

20 Zob. L. Gardocki, Kształtowanie polityki karnej drogq ustawodawcza, Studia Iuridica 1979 , t. 8, s. 62.

${ }^{21}$ Zob. tamże; zob. także M. Melezini, Środki karne..., s. 120. 
Nowododany art. 41a § 1a K.k. określa nową postać obligatoryjnego trybu orzekania zakazu. W razie skazania za przestępstwo przeciwko wolności seksualnej sąd, na wniosek pokrzywdzonego, zobligowany jest orzec zakaz kontaktowania się z pokrzywdzonym, zakaz zbliżania się do pokrzywdzonego lub nakaz okresowego opuszczenia lokalu zajmowanego wspólnie z pokrzywdzonym. Zakaz lub nakaz może być połączony z obowiązkiem zgłaszania się do Policji lub innego wyznaczonego organu w określonych odstępach czasu, a zakaz zbliżania się do pokrzywdzonego - również kontrolowany w systemie dozoru elektronicznego. Zauważyć trzeba, że złożenie wniosku zostało ograniczone przedmiotowo do przestępstw przeciwko wolności seksualnej. Zatem skazania za przestępstwa przeciwko obyczajności, jak również za przestępstwa przeciwko wolności oraz za umyślne przestępstwa z użyciem przemocy, nie uzasadniają orzeczenia tego środka karnego w trybie wnioskowym. Zgodnie ze znowelizowanym art. 49a § 2 Kodeksem postępowania karnego ${ }^{22}$ wniosek może być złożony przez pokrzywdzonego aż do zamknięcia przewodu sądowego na rozprawie głównej. Wniosek powinien odpowiadać wymogom pisma procesowego (art. 119 K.p.k.). Może on być złożony pisemnie lub ustnie do protokołu. Wniosek może być złożony przez pokrzywdzonego. Jeżeli pokrzywdzonym jest małoletni albo ubezwłasnowolniony całkowicie lub częściowo, prawa jego wykonuje przedstawiciel ustawowy albo osoba, pod której stałą pieczą pokrzywdzony pozostaje. Jeżeli pokrzywdzonym jest osoba nieporadna, w szczególności ze względu na wiek lub stan zdrowia, jego prawa może wykonywać osoba, pod której pieczą pokrzywdzony pozostaje (zob. art. 51 § 2 i 3 K.p.k.). Wnioskowy tryb orzekania przedmiotowego środka karnego niewątpliwie przyczyni się do poszerzenia zakresu ochrony pokrzywdzonego i zwiększy poczucie jego bezpieczeństwa. $Z$ drugiej strony rozwiązanie to ograniczy zakres swobody sądu i w skrajnych sytuacjach także może prowadzić do nadużyć, tym bardziej, że wnioskowy tryb nie został ograniczony do sytuacji, w których środek karny mógłby być zastosowany jedynie wobec sprawców skazanych na bezwzględną karę pozbawienia wolności. Przy ocenie tego rozwiązania nie można tracić z pola widzenia faktu, że jego dolegliwość jest poważna, tym bardziej, że może być połączona z obowiązkiem zgłaszania się do Policji lub innego wyznaczonego organu w określonych

22 Ustawa z dnia 6 czerwca 1997 r. - Kodeks postępowania karnego, tekst jednolity: Dz. U. z 2020 r. poz. 30 z późn. zm. (dalej: K.p.k.). 
odstępach czasu, a zakaz zbliżania się do pokrzywdzonego może być kontrolowany w systemie dozoru elektronicznego.

Odnośnie do art. 41a § 2 K.k. trzeba zauważyć, że jego normatywna zawartość obejmuje określenie przesłanek orzekania obligatoryjnego zakazu przebywania w określonych środowiskach lub miejscach, kontaktowania się z określonymi osobami, zbliżania się do określonych osób lub opuszczania określonego miejsca pobytu bez zgody sądu. W dotychczasowym kształcie obowiązek ten był uzależniony od skazania sprawcy na karę pozbawienia wolności bez warunkowego zawieszenia jej wykonania za przestępstwo przeciwko wolności seksualnej lub obyczajności na szkodę małoletniego. Nowelizacja z jednej strony przewiduje poszerzenie zakresu zastosowania środka karnego określonego w art. 41a § 2 K.k. poprzez stworzenie podstaw do jego orzeczenia nie tylko $\mathrm{w}$ razie skazania za przestępstwo przeciwko wolności seksualnej na szkodę małoletniego, ale także na szkodę każdej osoby. Z drugiej jednak strony, jak wyeksponowano $\mathrm{w}$ motywach ustawodawczych, uwzględniając charakter tych środków, ściśle związany z osobą pokrzywdzonego oraz interakcjami z innymi osobami, uznano, że ich orzekanie w sytuacji popełnienia przestępstwa skierowanego przeciwko obyczajności, a nie indywidualnym pokrzywdzonym, może niekiedy nie dać się należycie powiązać z charakterem przestępstwa (np. rozpowszechnianie pornografii), a w konsekwencji należało zrezygnować z obligatoryjnego orzekania tych środków za przestępstwa przeciwko obyczajności ${ }^{23}$.

Dokonując oceny zmian wynikających z noweli K.k. z czerwca 2019 r. nie można pomijać ratio legis, które uzasadniało wprowadzenie przedmiotowego środka karnego do K.k. w 2005 r. Uzasadnieniem wprowadzenia omawianej instytucji do katalogu środków karnych było wzmożenie ochrony osób małoletnich przed osobami dopuszczającymi się z pobudek seksualnych groźnych przestępstw o charakterze pedofilskim. W kształcie nadanym nowelą czerwcową, środek ten odrywa się od motywów ustawodawczych, które determinowały jego przyjęcie. Wydaje się, że na zmianę polegającą na stworzeniu podstaw do orzeczenia przedmiotowego środka karnego nie tylko w stosunku do sprawcy przestępstwa przeciwko wolności seksualnej popełnionego na szkodę małoletniego, ale także każdej innej osoby, należy patrzeć przez pryzmat eksponowanych

23 Zob. Sejm Rzeczypospolitej Polskiej VIII kadencja, Uzasadnienie $\mathrm{z}$ dnia 14 maja 2019 r. projektu ustawy..., s. 5. 
przez projektodawcę celów, mających uzasadnić nowelizację. Decydujące znaczenie przyznano funkcji ochronnej i - co się z tym wiąże - należytemu zabezpieczeniu pokrzywdzonego przestępstwem oraz potencjalnych ofiar. Prymat funkcji ochronnej zdecydował o nadaniu bardziej uniwersalnego charakteru temu środkowi karnemu, nieograniczonego do jednej kategorii sprawców.

Trudno o jednoznaczną ocenę zmiany polegającej na rezygnacji z obligatoryjnego trybu orzekania zakazu przebywania $\mathrm{w}$ określonych środowiskach lub miejscach, kontaktowania się z określonymi osobami, zbliżania się do określonych osób lub opuszczania określonego miejsca pobytu bez zgody sądu w razie skazania na karę pozbawienia wolności bez warunkowego zawieszenia jej wykonania za przestępstwo przeciwko obyczajności. Z jednej strony nie można nie dostrzec, że dotychczasowe rozwiązanie było nadmiernie restrykcyjne, co zresztą zauważano w piśmiennictwie, postulując ograniczenie zakresu tego środka karnego do skazania za przestępstwa przeciwko wolności seksualnej ${ }^{24}$. Z drugiej strony, uwzględniając regulacje Konwencji Organizacji Narodów Zjednoczonych o prawach dziecka z 1989 r. ${ }^{25}$, można powziąć wątpliwości, czy przyjęte rozwiązania nie wpłyną negatywnie na zakres ochrony małoletniego ${ }^{26}$. Konwencja nakłada na państwa-strony obowiązek podejmowania wszelkich kroków w sferze ustawodawczej zmierzających do ochrony dziecka przed wszelkimi formami przemocy, w tym wykorzystywania w celach seksualnych (art. 19). W świetle art. 34 konwencji, państwa-strony zobowiązują się do ochrony dzieci przed wszelkimi formami wyzysku seksualnego i nadużyć seksualnych. Dla osiągnięcia tych celów państwa-strony podejmą w szczególności wszelkie właściwe kroki o zasięgu krajowym, dwustronnym oraz wielostronnym dla przeciwdziałania: a) nakłanianiu lub zmuszaniu dziecka do jakichkolwiek nielegalnych działań seksualnych; b) wykorzystywania dzieci do prostytucji lub innych nielegalnych

24 Zob. A. Marek, Nieprzemyślane zaostrzenie kar za pedofilię, Rzeczpospolita 2005, nr 137.

25 Konwencja o prawach dziecka, przyjęta przez Zgromadzenie Ogólne Narodów Zjednoczonych dnia 20 listopada 1989 r., Dz. U. z 1991 r. Nr 120, poz. 526 z późn. zm.

${ }^{26}$ Zob. Rządowe Centrum Legislacji, Opinia z dnia 14 lutego 2019 r. dotycząca projektu ustawy z dnia 25 stycznia 2019 r. o zmianie ustawy - Kodeks karny oraz niektórych innych ustaw, https://legislacja.rcl.gov.pl/docs//2/12320403/12565603/12565606/dokument383421.pdf [dostęp: 9.07.2019 r.]. 
praktyk seksualnych; c) wykorzystywania dzieci w pornograficznych przedstawieniach i materiałach.

Zaproponowane rozwiązania, jakkolwiek tej ochrony dziecka nie pozbawiają, to jednak wprowadzają istotny wyłom, który może doprowadzić do dekompozycji systemu ochrony małoletnich.

\section{Zakaz kontaktowania się z określoną osobą}

W art. 41a § 6 K.k. ustawodawca doprecyzował treść zakazu kontaktowania się z określoną osobą. Zgodnie z nowym przepisem, zakaz kontaktowania się z określoną osobą obejmuje wszelkie czynności związane $\mathrm{z}$ próbą nawiązania kontaktu $\mathrm{z}$ osobą chronioną, $\mathrm{w}$ tym te podejmowane przez skazanego za pośrednictwem innej osoby lub z wykorzystaniem sieci teleinformatycznej. Chodzi więc o zachowania będące w swojej istocie usiłowaniem nawiązania kontaktu z osobą chronioną, a więc o wszelkie umyślne działania zmierzające do nawiązania kontaktu. Egzemplifikacją takiego zachowania jest wspomniana próba kontaktowania się przez inną osobę oraz za pośrednictwem systemu informatycznego, ale zakaz obejmuje również inne formy kontaktowania się z osobą chronioną. W świetle tego przepisu naruszeniem zakazu kontaktowania się będzie próba ustalenia adresu e-mail, próba kontaktu za pośrednictwem portali społecznościowych, komunikatorów, a także innych aplikacji umożliwiających kontakt zarówno werbalny, jak i wizualny. Mimo stanowczego i bezwarunkowego charakteru komentowanego przepisu, można poddać W wątpliwość, czy będzie naruszeniem zakazu kontaktowania się z inną osobą, sytuacja, w której dochodzi do wymiany korespondencji pomiędzy sprawcą a osobą chronioną, dotyczącej spraw urzędowych, dokonywanej za pośrednictwem profesjonalnego pełnomocnika (adwokata) ${ }^{27}$. Choć literalna wykładnia przemawia za przyjęciem, że i taki kontakt będzie stanowił pogwałcenie zakazu, to jednak muszą istnieć mechanizmy umożliwiające załatwienie spraw urzędowych wymagających kooperacji obydwu stron i dobrze byłoby, aby były one ustawowo określone (np. ustawowy

27 Zob. A. Marek, Kodeks karny. Komentarz, 2010 [baza danych LEX], Komentarz do art. $41 \mathrm{a}$, teza 5 . 
katalog określający wypadki, w których kontakt z pokrzywdzonym nie stanowiłby naruszenia zakazu).

\section{Zmiany $\mathrm{w}$ zakresie zakazu prowadzenia pojazdów}

Podniesienie poziomu represyjności uwidacznia się także w rozwiązaniach kształtujących odpowiedzialność karną za przestępstwa przeciwko bezpieczeństwu w komunikacji. Polegają one na uzupełnieniu katalogu przyczyn nadzwyczajnego obostrzenia kary wobec sprawców tych przestępstw $^{28}$. Konsekwencją tych zmian stała się także konieczność uzupełnienia podstaw orzekania obligatoryjnego zakazu prowadzenia pojazdów (art. 42 § 2 i 3 K.k. $)^{29}$.

28 Artykułowi 178 § 1 K.k. nadano brzmienie: Skazując sprawcę, który popełnił przestępstwo określone w art. 173, art. 174 lub art. 177 znajdując się w stanie nietrzeźwości lub pod wpływem środka odurzającego, zbiegł z miejsca zdarzenia lub spożywał napój alkoholowy lub zażywał środek odurzający po zdarzeniu, a przed poddaniem go przez uprawniony organ badaniu w celu ustalenia w organizmie zawartości alkoholu lub obecności środka działającego podobnie do alkoholu, sąd orzeka karę pozbawienia wolności przewidzianą za przypisane sprawcy przestępstwo w wysokości od dolnej granicy ustawowego zagrożenia zwiększonego o połowę, a w wypadku przestępstwa określonego w art. 177 § 2 w wysokości nie niższej niż 2 lata, do górnej granicy tego zagrożenia zwiększonego o połowę. Z kolei art. 178a § 4 K.k. otrzymał brzmienie: Jeżeli sprawca czynu określonego w § 1 był wcześniej prawomocnie skazany za prowadzenie pojazdu mechanicznego w stanie nietrzeźwości lub pod wpływem środka odurzającego albo za przestępstwo określone $\mathrm{w}$ art. 173, art. 174, art. 177 lub art. 355 § 2 popełnione w stanie nietrzeźwości lub pod wpływem środka odurzającego albo spożywał napój alkoholowy lub zażywał środek odurzający po zdarzeniu, a przed poddaniem go przez uprawniony organ badaniu w celu ustalenia w organizmie zawartości alkoholu lub obecności środka działającego podobnie do alkoholu albo dopuścił się czynu określonego w § 1 w okresie obowiązywania zakazu prowadzenia pojazdów mechanicznych orzeczonego w związku ze skazaniem za przestępstwo, podlega karze pozbawienia wolności od 3 miesięcy do lat 5.

${ }_{29}$ Artykuł 42 § 2 K.k. otrzymał brzmienie: § 2 . Sąd orzeka, na okres nie krótszy niż 3 lata, zakaz prowadzenia wszelkich pojazdów albo pojazdów określonego rodzaju, jeżeli sprawca w czasie popełnienia przestępstwa wymienionego w § 1 był w stanie nietrzeźwości, pod wpływem środka odurzającego, zbiegł z miejsca zdarzenia określonego w art. 173, art. 174 lub art. 177 lub spożywał napój alkoholowy lub zażywał środek odurzający po zdarzeniu określonym w art. 173, art. 174 lub art. 177, a przed poddaniem go przez uprawniony organ badaniu w celu ustalenia w organizmie zawartości alkoholu lub obecności środka działającego podobnie do alkoholu. 
Jak uwypuklono w uzasadnieniu projektu nowelizacji K.k. ${ }^{30}$ "aktualnie okolicznością szczególnie negatywnie charakteryzującą postawę sprawcy wobec popełnionego czynu, powstałą po jego popełnieniu [...] jest ucieczka z miejsca wypadku". Okoliczność ta, która - jak zauważa się w motywach ustawodawczych - ,jest uwarunkowana chęcią uniknięcia odpowiedzialności karnej przez sprawcę albo też złagodzenia tej odpowiedzialności, np. w sytuacji, gdy sprawca zdarzenia chce ukryć fakt znajdowania się pod wpływem alkoholu" ${ }^{31}$, dostarcza ustawodawcy racjonalizacji dla wprowadzenia nowej, „podobnej pod względem aksjologicznym" podstawy do nadzwyczajnego obostrzenia kary. Jest nią fakt spożywania napoju alkoholowego lub zażywania środka odurzającego po zdarzeniu, a przed poddaniem się badaniu mającym na celu ustalenie stanu sprawcy w chwili popełnienia przestępstwa po to, aby wykazywać, że w czasie popełnienia przestępstwa był trzeźwy lub nie był odurzony" ${ }^{32}$.

Jak dalej podkreśla się $\mathrm{w}$ uzasadnieniu:

zabiegi takie mogą zakończyć się powodzeniem, zwłaszcza gdy napój alkoholowy lub środek odurzający został spożyty krótko przed popełnieniem przestępstwa, co może być trudne albo wręcz niemożliwe do wykrycia przy użyciu metod badawczych stosowanych w aktualnym stanie wiedzy naukowej. Praktykę taką należy ocenić jednoznacznie krytycznie, prowadzi ona de facto do uprzywilejowania sprawców, którzy w ten sposób chcą doprowadzić do złagodzenia swej odpowiedzialności karnej, kosztem tych, którzy

Z kolei art. 42 § 3 K.k. otrzymał następującą treść: Sąd orzeka zakaz prowadzenia wszelkich pojazdów mechanicznych dożywotnio w razie popełnienia przestępstwa określonego $\mathrm{w}$ art. 178a $\S 4$ lub jeżeli sprawca w czasie popełnienia przestępstwa określonego w art. 173, którego następstwem jest śmierć innej osoby lub ciężki uszczerbek na jej zdrowiu, albo w czasie popełnienia przestępstwa określonego w art. 177 § 2 lub w art. 355 $\S 2$ był w stanie nietrzeźwości lub pod wpływem środka odurzającego, zbiegł z miejsca zdarzenia lub spożywał napój alkoholowy lub zażywał środek odurzający po zdarzeniu, a przed poddaniem go przez uprawniony organ badaniu w celu ustalenia $\mathrm{w}$ organizmie zawartości alkoholu lub obecności środka działającego podobnie do alkoholu, chyba że zachodzi wyjątkowy wypadek, uzasadniony szczególnymi okolicznościami.

30 Zob. uzasadnienie projektu ustawy o zmianie ustawy - Kodeks karny oraz niektórych innych ustaw, który wpłynął do Sejmu w dniu 19 maja 2019 r., s. 34, http:/ / orka. sejm.gov.pl/Druki8ka.nsf/Projekty/8-020-1321-2019/\$file/8-020-1321-2019.pdf [dostęp: 15.07.2019 r.].

31 Tamże.

32 Tamże, s. 34. 
pozostają na miejscu zdarzenia zgodnie z obowiązkiem wskazanym $\mathrm{w}$ art. 44 ust. 2 pkt 3 Pr.Drog. ${ }^{33}$

Przyjęte rozwiązania zostały skorelowane z nowelizacją ustawy Prawo o ruchu drogowym. Zgodnie z art. 44 ust. 2 pkt 2a tejże ustawy w nowym brzmieniu na kierującego pojazdem nałożono obowiązek polegający na powstrzymaniu się do czasu przybycia na miejsce wypadku Policji i poddania go badaniu w celu ustalenia w organizmie zawartości alkoholu lub obecności środka działającego podobnie do alkoholu od spożywania napojów alkoholowych i środków działających podobnie do alkoholu ${ }^{34}$.

Uchwalone zmiany opierają się na swoistego rodzaju domniemaniu, że każdy sprawca, który spożyje napój alkoholowy lub zażyje środek odurzający po czynie, zmierza do uchylenia się od odpowiedzialności karnej, poprzez uniemożliwienie udowodnienia mu, że alkohol lub środek odurzający znalazł się $\mathrm{w}$ jego organizmie już przed popełnieniem przestępstwa komunikacyjnego. Wydawać by się mogło, że przyjęta konstrukcja domniemania pozwoli ominąć sądom trudności dowodowe, jakie napotykają w związku z koniecznością udowodnienia faktu wprawienia się

33 Tamże.

34 W wyniku nowelizacji art. 44 ustawy z dnia 20 czerwca 1997 r. - Prawo o ruchu drogowym (tekst jednolity: Dz. U. z 2020 r. poz. 110 zyskał następujące brzmienie:

Art. 44.1 Kierujący pojazdem w razie uczestniczenia w wypadku drogowym jest obowiązany:

1) zatrzymać pojazd, nie powodując przy tym zagrożenia bezpieczeństwa ruchu drogowego;

2) przedsięwziąć odpowiednie środki w celu zapewnienia bezpieczeństwa ruchu w miejscu wypadku;

3) niezwłocznie usunąć pojazd z miejsca wypadku, aby nie powodował zagrożenia lub tamowania ruchu, jeżeli nie ma zabitego lub rannego;

4) podać swoje dane personalne, dane personalne właściciela lub posiadacza pojazdu oraz dane dotyczące zakładu ubezpieczeń, z którym zawarta jest umowa obowiązkowego ubezpieczenia odpowiedzialności cywilnej, na żądanie osoby uczestniczącej w wypadku.

2. Jeżeli w wypadku jest zabity lub ranny, kierujący pojazdem jest obowiązany ponadto:

1) udzielić niezbędnej pomocy ofiarom wypadku oraz wezwać zespół ratownictwa medycznego i Policję;

2) nie podejmować czynności, które mogłyby utrudnić ustalenie przebiegu wypadku;

2a) do czasu przybycia na miejsce wypadku Policji i poddania go badaniu w celu ustalenia w organizmie zawartości alkoholu lub obecności środka dziatającego podobnie do alkoholu powstrzymać się od spożywania napojów alkoholowych i środków działających podobnie do alkoholu;

3) pozostać na miejscu wypadku, a jeżeli wezwanie zespołu ratownictwa medycznego lub Policji wymaga oddalenia się - niezwłocznie powrócić na to miejsce. 
przez sprawcę w stan nietrzeźwości lub odurzenia i drobiazgowego ustalania, czy okoliczność ta miała miejsce przed czy po inkryminowanym czynie. Tak jednak nie jest. W nowym stanie prawnym, sąd będzie zobligowany do ustalenia zarówno tego, czy sprawca w czasie czynu znajdował się w stanie nietrzeźwości lub odurzenia, jak też do tego, czy w stan ten wprawił się dopiero po czynie i to niezależnie od tego, że następstwa obydwu tych stanów (spożycie napoju alkoholowego lub zażycie środka odurzającego przed czynem albo po nim) w zakresie wymiaru kary (nadzwyczajne obostrzenie kary), jak i wymiaru środków karnych, są analogiczne. Jak słusznie podkreślają autorzy opinii:

niedopuszczalne jest bowiem ograniczenie się organu rozstrzygającego sprawę do stwierdzenia, że sprawca w chwili przeprowadzania badania na obecność w organizmie niedozwolonych środków był w stanie po ich spożyciu. Formuła wyroku „warunkowego" obejmującego ustalenie sądu, iż sprawca wprawił się w stan nietrzeźwości przed lub „co najmniej” po zdarzeniu, z tej perspektywy nie wydaje się być do zaakceptowania ${ }^{35}$.

Do analogicznych wniosków doszli autorzy innej opinii jednoznacznie stwierdzając, że:

wydając orzeczenie, sąd nie może bowiem uznać, że to wszystko jedno, skoro kara i tak będzie zaostrzona. Sąd nie może też wydać wyroku warunkowego w postaci stwierdzenia, że „nawet gdyby sprawca nie był pod wpływem alkoholu w czasie czynu, to pewnie wypił po czynie". W braku wyjaśnień sprawcy sąd i tak będzie teraz musiał rozstrzygać, kiedy nastąpiło spożycie środka. Do tej pory interesował sąd wyłącznie czas popełnienia przestępstwa komunikacyjnego. Po zmianach będzie musiał nadto ustalać stan sprawcy po popełnieniu tego przestępstwa ${ }^{36}$.

35 Katedra Prawa Karnego Materialnego Uniwersytetu Wrocławskiego, Opinia na temat projektu zmian przepisów kodeksu karnego (uchwała Senatu Rzeczypospolitej Polskiej z dnia 24 maja 2019 roku), oprac. J. Giezek, K. Lipiński, s. 46, https:/ / www.rpo.gov. $\mathrm{pl} /$ sites/default/files/Opinia \% 20Katedry\%20Prawa \% 20Karnego\% 20Materialnego \% 20 WPAE\%20UWr\%20do\%20nowelizacji\%20kodeksu\%20karnego.pdf [dostęp: 12.07.2019 r.].

36 Krakowski Instytut Prawa Karnego, Opinia z dnia 20 maja 2019 r. w sprawie uchwalonej przez Sejm Rzeczypospolitej Polskiej na 81. posiedzeniu w dniu 16 maja 2019 r. ustawy o zmianie ustawy - Kodeks karny oraz niektórych innych ustaw, oprac. A. Barczak-Oplustil i in., Druk senacki Nr 1184, s. 23, https:/ / www.rpo.gov.pl/sites/default/files/ Opinia \%20Krakowskiego\%20Instytutu \%20Prawa\%20Karnego \%2C\%2020\%20maja \% 20 2019.pdf [dostęp: 12.07.2019 r.]. 
Rozwiązania prowadzące do zaostrzenia odpowiedzialności karnej z uwagi na spożycie alkoholu lub substancji odurzającej po popełnieniu czynu zabronionego spotkały się z różnymi ocenami. Obok wypowiedzi afirmatywnych ${ }^{37}, \mathrm{w}$ stosunku do uchwalonych przepisów sformułowano także istotne uwagi krytyczne. Najdalej idąca dotyczyła traktowania spożywania alkoholu po zdarzeniu na równi z prowadzeniem pojazdu w stanie nietrzeźwości lub odurzenia czy nawet ucieczki. Regulację tę uznano za sprzeczną z zasadą proporcjonalności ${ }^{38}$. Ponadto podniesiono zarzut, że przyjęte rozwiązania mają stanowić panaceum na trudności dowodowe, jakie wymiar sprawiedliwości może napotkać w stosunku do sprawców przestępstw komunikacyjnych, którzy w trakcie ich popełnienia znajdowali się w stanie nietrzeźwości lub byli pod wpływem środka odurzającego i dążąc do uchylenia się od odpowiedzialności spożyją napój alkoholowy lub zażyją środek odurzający już po czynie, co ma uniemożliwić udowodnienie, że alkohol lub środek odurzający znalazł się w organizmie sprawcy już przed popełnieniem przestępstwa komunikacyjnego ${ }^{39}$. Retorycznie pytano, czy dopuszczalne jest, w imię zapobiegania trudnościom

37 Zob. wypowiedź b. ministra sprawiedliwości Z. Ćwiąkalskiego, który zauważył, że: „Dobry jest przepis, który mówi, że kierowca po spowodowaniu wypadku będzie musiał doczekać na badania w celu ustalenia, czy w jego organizmie nie ma alkoholu lub innego środka podobnie działającego. $W$ tej chwili pijani kierowcy, którzy oddalili się z miejsca wypadku, tłumaczą się, że byli tak zdenerwowani, że musieli się napić", "Przeglad": Prawny populizm [online], serwis internetowy Interia Fakty, https://fakty.interia.pl/polska/news-przeglad-prawny-populizm, nId, 3074453 [dostęp: 12.07.2019 r.]. Zasadniczo aprobatywnie (choć niebezkrytycznie) do propozycji uzupełnienia katalogu przyczyn uzasadniających nadzwyczajne obostrzenie kary wobec sprawców przestępstw przeciwko bezpieczeństwu w komunikacji ustosunkowała się A. Muszyńska, zob. Katedra Prawa Karnego Materialnego Uniwersytetu Wrocławskiego, Opinia z dnia 30 kwietnia 2019 r. Ośrodka Badań, Studiów i Legislacji Krajowej Rady Radców Prawnych na temat projektu z dnia 5 kwietnia 2019 r. o zmianie ustawy Kodeks karny oraz niektórych innych ustaw, oprac. A. Muszyńska, http://obsil.pl/wp-content/uploads/2019/06/Opinia-z-30.04.2019-r.-KK-II.pdf [dostęp: 12.07.2019 r.].

38 Zob. Rzecznik Praw Obywatelskich, Stanowisko wyrażone na piśmie do Ministra Sprawiedliwości z dnia 14 lutego 2019 r. - uwagi do projektu ustawy o zmianie ustawy - Kodeks karny oraz niektórych innych ustaw, https:/ / www.rpo.gov.pl/sites/default/files/Wyst\%C4\%85pienie \%20do\%20Ministra\%20Sprawiedliwo \% C5\%9Bci\%20\%20ws. \%20 propozycji\%20zmian\%20w\%20Kodeksie\%20karnym.pdf [dostęp: 12.07.2019 r.].

39 Zob. uwagi krytyczne sformułowane w: Krakowski Instytut Prawa Karnego, Opinia z dnia 20 maja 2019 r. w sprawie uchwalonej przez Sejm Rzeczypospolitej Polskiej na 81. posiedzeniu w dniu 16 maja 2019 r. ustawy..., oprac. A. Barczak-Oplustil i in.; zob. 
dowodowym, wymaganie, aby człowiek - sprawca zdarzenia w komunikacji, zwłaszcza naznaczonego tragicznymi skutkami - pozostając niewątpliwie w anormalnym stanie psychiki, bezwzględnie unikał stosowania środków, które w sytuacji niewątpliwe głębokiego stresu powypadkowego mogą jego psychice ulżyć ${ }^{40}$.

Zauważyć również trzeba dostrzeżoną przez A. Muszyńską ${ }^{41}$ niekonsekwencję ustawodawcy, wyrażającą się w tym, że w art. 42 § 2 i 3, art. 178, art. 178a K.k. posługuje się on terminami „pod wpływem środka odurzającego", „zażycie środka odurzającego" i równolegle pojęciem „obecność środka działającego podobnie do alkoholu". Jak zauważa, ostatnie z wymienionych pojęć wiąże się z wieloma, wskazywanymi już w literaturze przedmiotu, wątpliwościami interpretacyjnym i nie może być dowolnie zestawiane ze "środkiem odurzającym”.

W kontekście analizowanej zmiany dotyczącej zakazu prowadzenia pojazdu należy zwrócić uwagę na niespójność przyjętych regulacji, która ujawnia się po zestawieniu treści znowelizowanych przepisów: art. $42 \S 2$ K.k. i art. 44 ust. 2 pkt 2 ustawy Prawo o ruchu drogowym. Po wejściu $\mathrm{w}$ życie nowelizacji jedną z okoliczności uzasadniających obligatoryjne orzeczenie zakazu prowadzenia pojazdów stanie się spożycie napoju alkoholowego lub zażycie środka odurzającego po zdarzeniu określonym w art. 173, art. 174 lub art. 177 K.k., a przed poddaniem sprawcy przez uprawniony organ badaniu w celu ustalenia w organizmie zawartości alkoholu lub obecności środka działającego podobnie do alkoholu. Tymczasem zgodnie z treścią art. 44 ust. 2 pkt 2a ustawy Prawo o ruchu drogowym w brzmieniu nadanym ustawą z dnia 13 czerwca 2019 r., jeżeli w wypadku jest zabity lub ranny, kierujący pojazdem jest obowiązany do czasu przybycia na miejsce wypadku Policji i poddania go badaniu w celu ustalenia w organizmie zawartości alkoholu lub obecności środka działającego podobnie do alkoholu powstrzymać się od spożywania napojów alkoholowych i środków działających podobnie do alkoholu.

także Katedra Prawa Karnego Materialnego Uniwersytetu Wrocławskiego, Opinia na temat projektu zmian przepisów kodeksu karnego..., oprac. J. Giezek, K. Lipiński.

40 Zob. Katedra Prawa Karnego Materialnego Uniwersytetu Wrocławskiego, Opinia na temat projektu zmian przepisów kodeksu karnego..., oprac. J. Giezek, K. Lipiński, s. 46.

${ }^{41}$ Zob. Katedra Prawa Karnego Materialnego Uniwersytetu Wrocławskiego, Opinia z dnia 30 kwietnia 2019 r. Ośrodka Badań, Studiów i Legislacji Krajowej Rady Radców Prawnych na temat projektu z dnia 5 kwietnia 2019 r. ..., oprac. A. Muszyńska. 
W świetle orzecznictwa Sądu Najwyższego wypadek, w którym są zabici lub ranni to taki wypadek, w którym co najmniej jedna osoba poniosła śmierć, uległa ciężkiemu lub lekkiemu uszkodzeniu ciała bądź ciężkiemu lub lekkiemu rozstrojowi zdrowia ${ }^{42}$. Zgodnie z dominującym stanowiskiem doktryny w art. 44 ust. 2 ustawy Prawo o ruchu drogowym chodzi o wypadek drogowy, którego następstwem są skutki na osobie, tj. śmierć, ciężki uszczerbek na zdrowiu, średnie (naruszające czynności narządu ciała lub rozstrój zdrowia trwający dłużej niż 7 dni) lub lekkie obrażenia ciała (naruszające czynności narządu ciała lub rozstrój zdrowia trwający nie dłużej niż $7 \mathrm{dni}$ ). W pojęciu tym mieści się więc wypadek drogowy określony w art. 177 § 1 i 2 K.k. oraz art. 355 § 1 i 2 K.k. (w zakresie obrażeń ciała) oraz wyczerpujący znamiona wykroczenia z art. 86 $\S 1$ Kodeksu wykroczeń ${ }^{43}$ (w zakresie lekkich obrażeń ciała), a także sprowadzenie katastrofy w ruchu drogowym, której następstwem są obrażenia ciała (art. 173 K.k.) ${ }^{44}$. Jak zasadnie zauważa się, w przypadku przestępstwa sprowadzenia niebezpieczeństwa katastrofy komunikacyjnej (art. 174 K.k.), czyn taki nie musi łączyć się ze spowodowaniem wypadku w komunikacji, a tym samym ze skutkami w postaci śmierci człowieka czy obrażeń ciała ${ }^{45}$. W tej sytuacji na sprawcy nie ciąży zatem obowiązek powstrzymania się od spożywania napojów alkoholowych i środków działających podobnie do alkoholu, choć - jak się wydaje - intencją ustawodawcy było, aby znowelizowany przepis art. 44 ust. 2 pkt 2a ustawy Prawo o ruchu drogowym sankcjonował każdorazowe spożycie napoju alkoholowego lub zażycie środka odurzającego po zdarzeniu określonym w art. 173, art. 174 i art. 177 K.k., niezależnie od skutków. Niestety nie znalazło to odzwierciedlenia $\mathrm{w}$ treści znowelizowanych przepisów ustawy Prawo o ruchu drogowym, co będzie powodować określone problemy interpretacyjne i poddawać w wątpliwość racjonalność ustawodawcy.

42 Zob. wyrok SN z dnia 22 grudnia 1992 r., III KRN 149/92, LEX nr 22082 wraz z glosą aprobującą R.A. Stefańskiego, zob. tenże, Pojęcie wypadku drogowego oraz obowiązek uczestnika wypadku udzielenia pomocy osobie w nim poszkodowanej. Glosa do wyroku SN z dnia 22 grudnia 1992 r., III KRN 149/92, Państwo i Prawo 1993, nr 5, s. 113.

43 Ustawa z dnia 20 maja 1971 r. - Kodeks wykroczeń, tekst jednolity: Dz. U. z 2019 r. poz. 821 z późn. zm.

44 Zob. R.A. Stefański, Prawo o ruchu drogowym. Komentarz, 2008 [baza danych LEX].

45 Zob. Krakowski Instytut Prawa Karnego, Opinia z dnia 20 maja 2019 r. w sprawie uchwalonej przez Sejm Rzeczypospolitej Polskiej na 81. posiedzeniu w dniu 16 maja 2019 r. ustawy..., oprac. A. Barczak-Oplustil i in., s. 22-23. 


\section{Podsumowanie}

Zasadniczym motywem zmian odnoszących się do środków karnych było zwalczanie przestępczości pedofilskiej oraz komunikacyjnej. Ustawodawca - ze względu na rangę tych dóbr oraz niedostateczny (w jego ocenie) poziom ich ochrony, jak również konieczność realizacji funkcji ochronnej - zdecydował się na dosyć głęboką ingerencję w dotychczasowy system środków karnych. Polegała ona w głównej mierze na ograniczeniu swobody sędziowskiej, poprzez poszerzenie obligatoryjnych podstaw orzekania przedmiotowych środków karnych oraz zwielokrotnieniu przesłanek ich zastosowania. Wdrożone zmiany są wyrazem nowej aksjologii prawa karnego i jego reorientacji w kierunku zaostrzenia represji karnej ${ }^{46}$. Wpisują się one w nowy, znacznie bardziej represyjny, kierunek polityki karnej. Są one wyrazem nowej filozofii karania, znacznie różniącej się od tej, która uzasadniała wprowadzenie do systemu polskiego prawa karnego środków karnych.

Słowa kluczowe: prawo karne, nowelizacja kodeksu karnego, środki karne, zakaz prowadzenia pojazdów

\section{Bibliografia}

\section{Źródła}

\section{Akty prawne}

Konwencja o prawach dziecka, przyjęta przez Zgromadzenie Ogólne Narodów Zjednoczonych dnia 20 listopada 1989 r., Dz. U. z 1991 r. Nr 120, poz. 526 z późn. zm.

Ustawa z dnia 6 czerwca 1997 r. - Kodeks karny, tekst jednolity: Dz. U. z 2019 r. poz. 1950 z późn. zm.

Ustawa z dnia 6 czerwca 1997 r. - Kodeks postępowania karnego, tekst jednolity:

Dz. U. z 2020 r. poz. 30 z późn. zm.

Ustawa z dnia 20 czerwca 1997 r. - Prawo o ruchu drogowym, tekst jednolity:

Dz. U. z 2020 r. poz. 110.

46 Zjawisko to dostrzegła już M. Melezini, zob. taż, Spójność prawa karnego a zmiany w zakresie kar i zasad ich wymiaru, w: Problem spójności..., s. 89. 
Ustawa z dnia 18 marca 2004 r. o zmianie ustawy - Kodeks karny, ustawy - Kodeks postępowania karnego oraz ustawy - Kodeks wykroczeń, Dz. U. z 2004 r. Nr 69, poz. 626.

Ustawa z dnia 27 lipca 2005 r. o zmianie ustawy - Kodeks karny, ustawy - Kodeks postępowania karnego i ustawy - Kodeks karny wykonawczy, Dz. U. z 2005 r. Nr 163, poz. 1363.

Ustawa z dnia 24 października 2008 r. o zmianie ustawy - Kodeks karny oraz niektórych innych ustaw, Dz. U. z 2008 r. Nr 214, poz. 1344.

Ustawa z dnia 5 listopada 2009 r. o zmianie ustawy - Kodeks karny, ustawy Kodeks postępowania karnego, ustawy - Kodeks karny wykonawczy, ustawy - Kodeks karny skarbowy oraz niektórych innych ustaw, Dz. U. z 2009 r. Nr 206, poz. 1589.

Ustawa z dnia 13 czerwca 2019 r. o zmianie ustawy - Kodeks karny oraz niektórych innych ustaw, http://orka.sejm.gov.pl/opinie8.nsf/nazwa/3451_u/\$file /3451_u.pdf [dostęp: 8.07.2019 r.].

\section{Orzecznictwo}

Wyrok SN z dnia 22 grudnia 1992 r., III KRN 149/92, LEX nr 22082.

\section{Projekty ustaw, uzasadnienia projektów ustaw i opinie}

Katedra Prawa Karnego Materialnego Uniwersytetu Wrocławskiego, Opinia na temat projektu zmian przepisów kodeksu karnego (uchwała Senatu Rzeczypospolitej Polskiej z dnia 24 maja 2019 r.), oprac. J. Giezek, K. Lipiński, https://www.rpo.gov.pl/sites/default/files/Opinia\%20Katedry\%20 Prawa \%20Karnego\%20Materialnego\%20WPAE\%20UWr\%20do\%20nowelizacji\%20kodeksu \%20karnego.pdf [dostęp: 12.07.2019 r.].

Katedra Prawa Karnego Materialnego Uniwersytetu Wrocławskiego, Opinia z dnia 30 kwietnia 2019 r. Ośrodka Badań, Studiów i Legislacji Krajowej Rady Radców Prawnych na temat projektu z dnia 5 kwietnia 2019 r. o zmianie ustawy Kodeks karny oraz niektórych innych ustaw, oprac. A. Muszyńska, http://obsil.pl/wp-content/uploads/2019/06/Opinia-z-30.04.2019-r.-KK-II. pdf [dostęp: 12.07.2019 r.].

Krakowski Instytut Prawa Karnego, Opinia z dnia 20 maja 2019 r. w sprawie uchwalonej przez Sejm Rzeczypospolitej Polskiej na 81. posiedzeniu w dniu 16 maja 2019 r. ustawy o zmianie ustawy - Kodeks karny oraz niektórych innych ustaw, oprac. A. Barczak-Oplustil i in., Druk senacki Nr 1184, https:/ / www. rpo.gov.pl/sites/default/files/Opinia \% 20Krakowskiego \% 20Instytutu \% 20 Prawa\%20Karnego\%2C\%2020\%20maja\%202019.pdf [dostęp: 12.07.2019 r.].

Projekt z dnia 25 stycznia 2019 r. ustawy o zmianie ustawy - Kodeks karny oraz niektórych innych ustaw, https://legislacja.rcl.gov.pl/docs//2/12320403/ 12565603/12565604/dokument378684.pdf [dostęp: 19.02.2019 r.]. 
Rządowe Centrum Legislacji, Opinia z dnia 14 lutego 2019 r. dotycząca projektu ustawy z dnia 25 stycznia 2019 r. o zmianie ustawy - Kodeks karny oraz niektórych innych ustaw, https:/ / legislacja.rcl.gov.pl/docs//2/12320403/1256 5603/12565606/dokument383421.pdf [dostęp: 9.07.2019 r.].

Rzecznik Praw Obywatelskich, Stanowisko wyrażone na piśmie do Ministra Sprawiedliwości z dnia 14 lutego 2019 r. - uwagi do projektu ustawy o zmianie ustawy - Kodeks karny oraz niektórych innych ustaw, https://www. rpo.gov.pl/sites/default/files/Wyst\% C4\% 85pienie\%20do\%20Ministra\% 20 Sprawiedliwo\%C5\%9Bci\%20\%20ws. \%20propozycji \%20zmian \%20w\%20Kodeksie\%20karnym.pdf [dostęp: 6.03.2020 r.].

Sejm Rzeczypospolitej Polskiej VIII kadencja, Uzasadnienie z dnia 14 maja 2019 r. projektu ustawy o zmianie ustawy - Kodeks karny oraz niektórych innych ustaw, Druk Nr 3451, http:/ / orka.sejm.gov.pl/Druki8ka.nsf/0/996CE30712 3D03FEC12583FA0069E8F2/\%24File/3451.pdf [dostęp: 5.06.2019 r.].

\section{Literatura}

Gardocki L., Ksztattowanie polityki karnej droga ustawodawcza, Studia Iuridica 1979, t. 8.

Kaczmarek T., Nowy polski kodeks karny i jego aksjologiczne i kryminalnopolityczne założenia, Nowa Kodyfikacja Prawa Karnego 1998, t. 3.

Mamak K., Zakaz korzystania z serwisów społecznościowych. Propozycja wprowadzenia nowego środka karnego, Czasopismo Prawa Karnego i Nauk Penalnych 2016, z. 3.

Marek A., Kodeks karny. Komentarz, 2010 [baza danych LEX].

Marek A., Nieprzemyślane zaostrzenie kar za pedofilię, Rzeczpospolita 2005, nr 137.

Melezini M., Spójność prawa karnego a zmiany w zakresie kar $i$ zasad ich wymiaru, w: Problem spójności prawa karnego z perspektywy jego nowelizacji, red. A. Marek, T. Oczkowski, Warszawa 2011.

Melezini M., Środki karne jako instrument polityki kryminalnej, Białystok 2013.

Sienkiewicz Z., Z problematyki środków karnych, w: Węzłowe problemy prawa karnego, kryminologii i polityki kryminalnej. Księga pamiątkowa ofiarowana Profesorowi Andrzejowi Markowi, red. V. Konarska-Wrzosek, J. Lachowski, J. Wójcikiewicz, Warszawa 2010.

Stefański R.A., Pojęcie wypadku drogowego oraz obowiązek uczestnika wypadku udzielenia pomocy osobie w nim poszkodowanej. Glosa do wyroku SN z dnia 22 grudnia 1992 r., III KRN 149/92, Państwo i Prawo 1993, nr 5.

Stefański R.A., Prawo o ruchu drogowym. Komentarz, 2008 [baza danych LEX].

Stefański R.A., Nowe środki karne i problem ich spójności z systemem Kodeksu karnego, w: Problem spójności prawa karnego z perspektywy jego nowelizacji, red. A. Marek, T. Oczkowski, Warszawa 2011. 
"Przeglad": Prawny populizm [online], serwis internetowy Interia Fakty, https:// fakty.interia.pl/polska/news-przeglad-prawny-populizm, nId, 3074453 [dostęp: 12.07.2019 r.].

Szeleszczuk D., Środki karne w świetle nowelizacji Kodeksu karnego z dnia 20 lutego 2015 r., Studia Prawnicze KUL 2015, nr 4.

Wiak K., Nowe tendencje w zakresie przeciwdziatania przestęstwom zwiazanym z wykorzystywaniem dzieci w celach seksualnych na tle nowelizacji Kodeksu karnego, w: Nauki penalne wobec szybkich przemian socjokulturowych. Ksiega jubileuszowa Profesora Mariana Filara, t. 1, red. A. Adamski i in., Torun 2012.

Zoll A., Głos w dyskusji, w: Czy trzeba zmieniać kodeks karny? Materiaty z konferencji naukowej „Nowelizacja kodeksu karnego", Warszawa, 10 lutego 2003 r., Warszawa 2003.

\section{CHANGES IN TERMS OF PENAL MEASURES IN THE LIGHT OF THE AMENDMENT TO THE PENAL CODE OF 13 JUNE 2019}

\section{Summary}

Changes in penal measures resulting from the amendment to the Penal Code of 13 June 2019 constitute the subject matter of the article. The author analyses the consequences of those changes. The authors of the amendments to the act declared that the level would increase the protection of children through criminal law, which was their main motive. The article reveals various errors and disadvantages of the legal framework adopted, which do not allow for a positive assessment of the above mentioned amendment. The article also raises the issues related to changes accounting for a criminal measure in the form of a driving ban. The article refers to the amendments to the Criminal Code, which resulted in significant strengthening of criminal liability for transport crime. The author gives a critical review and demonstrates the fallacy of certain provisions and their inconsistency with other Code stipulations. Furthermore, taking such radical measures - contrary to what the amendment authors pointed out - is not justified by the increasing crime rate. The author is critical about the proposed amendments, emphasising their excessive repressiveness, which is not reasoned by the need to protect traffic safety.

Key words: criminal law, amendment to the Penal Code, penal measures, driving ban 


\section{ИЗМЕНЕНИЯ В ОБЪЕМЕ УГОЛОВНЫХ МЕР В СВЕТЕ ВНЕСЕНИЯ ИЗМЕНЕНИЯ В УГОЛОВНЫЙ КОДЕКС 13 ИЮНЯ 2019 ГОДА}

\section{Резюме}

Предметом статьи являются изменения в уголовных мерах в результате внесения изменений в Уголовный кодекс 13 июня 2019 года. Автор анализирует последствия этих изменений.

По мнению авторов проекта, основной целью является повышение уровня защиты детей с помощью уголовного законодательства. В статье раскрываются различные ошибки и недостатки принятых правовых решений, которые не позволяют дать положительную оценку вышеуказанных изменений. В статье также поднимаются вопросы, связанные с изменениями меры уголовного наказания в виде запрета на вождение автосредств. В статье упоминаются изменения, внесенные в Уголовный кодекс, которые привели к значительному увеличению уголовной ответственности лиц, совершивших преступления, связанные с дорожным движением. Автор проводит критический анализ и показывает несовершенность некоторых положений и их несоответствие другим решениям кодекса. Более того, принятие таких радикальных мер - вопреки тому, что заметили авторы изменений не оправдано уровнем и динамикой преступлений, связанных с дорожным движением. Автор критикует предложенные изменения, подчеркивая их чрезмерную репрессивность, которая не оправдана необходимостью обеспечения безопасности в дорожном движении.

Ключевые слова: уголовное право, внесение изменений в Уголовный кодекс, уголовные меры, запрет на вождение 
